Narrative Review

\title{
Chemometrics Application for Grouping and Determinating Volatile Compound which related to Antioxidant Activity of Turmeric Essential Oil (Curcuma longa)
}

\author{
Aplikasi Kemometrika dalam Mengelompokkan dan Menentukan Korelasi Senyawa \\ Mudah Menguap terhadap Aktivitas Antioksidan Minyak Atsiri Kunyit (Curcuma longa) \\ Rosy Islamadina', Adelin Chan', and Abdul Rohman ${ }^{2,3 *}$ \\ 1 Fakultas Farmasi Universitas Gadjah Mada, Yogyakarta 55281 Indonesia \\ 2 Departemen Kimia Farmasi, Fakultas Farmasi, Universitas Gadjah Mada, Yogyakarta 55281 Indonesia \\ 3 Institute of Halal Industry and Systems, Universitas Gadjah Mada, Yogayakarta, 55281, Indonesia \\ *Corresponding author: Abdul Rohman I Email: abdulrohmanugm@gmail.com
}

Received: 16 June 2020; Revised: 24 July 2020; Accepted: 2 August 2020; Published: 26 October 2020

\begin{abstract}
Turmeric essential oil is known to have antioxidant activity. Various in vitro antioxidant activity assays has been carried out. Related to this research, it tries to examine the antioxidant potential of turmeric essential oil and see the composition that is responsible for antioxidant activity combine with chemometrics. The research method used was a narrative review of 60 articles obtained from several databases. The review conducted on profiling essential oil compounds that identified using GC-MS and evaluation of the antioxidant activity of turmeric essential oil with the most commonly used method including scavenging radical 2,2 diphenyl-1picrylhydrazyl (DPPH) and 2,2-azinobis (3-ethylbenzothiazoline-6 sulfonic acid (ABTS). Analysis methods used for grouping various multivariate data subjects and determaining the relationship between the variables were Principal Component Analysis (PCA) and Cluster Analysis (CA). According to the review, turmeric essential oils are proven to have potential antioxidant activity and have variations in chemical contents. PCA was success for grouping subjects with various correlated variables, determining variables wich the most influential and correlation between variables. CA method can be used to group samples without requiring mutually correlated variables.
\end{abstract}

Keywords: turmeric essential oil; GC-MS profiling; antioxidant activity; partial component analysis; cluster analysis.

Abstrak: Minyak atsiri kunyit dilaporkan memiliki aktivitas antioksidan yang berkaitan dengan kandungan
senyawa di dalamnya. Beberapa metode uji in vitro untuk mengevaluasi aktivitas antioksidan minyak atsiri telah
banyak dilakukan. Oleh karena itu, penelitian ini bertujuan untuk melakukan review potensi antioksidan minyak
atsiri kunyit dan melihat senyawa yang bertanggungjawab terhadap aktivitas antioksidan dengan bantuan
analisis kemometrika. Metode penelitian yang dilakukan adalah narrative review dari 60 literatur yang diperoleh
dari beberapa database. Review yang dilakukan difokuskan pada profiling senyawa minyak atsiri kunyit yang
diindentifikasi menggunakan gas chromatography-mass spectrometry (GC-MS) dan evaluasi aktivitas antioksidan
minyak atsiri kunyit dengan metode yang paling umum digunakan yaitu penangkapan radikal 2,2 diphenyl-1-
picryhydrazyl (DPPH) dan 2,2-azinobis(3-ethylbenzothiazoline-6 suslfonic acid (ABTS). Metode analisis yang
J.Food Pharm.Sci. 2020,8(2), 225-239 ww.journal.ugm.ac.id/v3/JFPS 
digunakan untuk tujuan pengelompokan subjek dan mencari korelasi antar variabelnya adalah Principal Component Analysis (PCA) dan Cluster Analysis (CA). Menurut hasil review yang telah dilakukan, minyak atsiri kunyit terbukti memiliki aktivitas antioksidan yang poten dan kandungan senyawa yang bervariasi. Penggunaan teknik PCA berhasil mengelompokkan subjek dengan berbagai variabel yang berkorelasi, menentukan variabel yang paling berpengaruh, dan melihat korelasi antar variabel. Begitu juga teknik CA dapat digunakan untuk mengelompokkan sampel tanpa mensyaratkan variabel yang saling berkorelasi.

Kata kunci: Minyak atsiri kunyit; GC-MS profiling; antioksidan; Principal Component Analysis; Cluster Analysis

\section{PENDAHULUAN}

Kunyit merupakan herba medika yang mudah dibudidayakan dan banyak terdapat di seluruh belahan bumi. Kunyit dilaporkan memiliki banyak khasiat diantaranya adalah sebagai antioksidan [1-5], antiinflamasi [6], antimikroba [7], anti-fungi [8], dan anti kanker [9]. Senyawa radikal di tubuh dalam bentuk reactive oxygen species (ROS) yang di atas kadar normal dapat memicu beberapa penyakit seperti hipertensi, aterosklerosis, diabetes, gagal jantung, stroke, dan penyakit kronis lainnya [10].

Kandungan utama rimpang kunyit adalah kurkuminoid dan minyak atsiri (essential oil). Minyak atsiri kunyit dilaporkan dapat digunakan sebagai antioksidan alami yang poten, sehingga dapat mencegah stres oksidatif pada manusia dengan mekanisme menurunkan pelepasan hormon kortisol dan meningkatkan aktivitas enzim antioksidan [11]. Oleh karena itu, penelitian ini akan membahas mengenai profil senyawa minyak atsiri kunyit yang diidentifikasi menggunakan gas chromatography-mass spectrometry (GC-MS) yang berkorelasi terhadap aktivitas antioksidannya. Hasil profiling senyawa yang dikaitkan dengan bioaktivitasnya memungkinkan diperoleh penemuan senyawa baru yang kedepannya dapat dimanfaatkan untuk pengembangan senyawa kompleks yang berasal dari bahan alam untuk tujuan terapi [12].

Tanaman obat yang berasal dari habitat yang berbeda akan memiliki kandungan yang beragam sehingga menghasilkan data yang bervariasi, sehingga diperlukan metode kemometrika dalam pengolahan datanya [13]. Perbedaan beberapa variabel terkontrol dapat dikelompokkan ke dalam beberapa kluster menggunakan teknik analisis kemometrika Principal Component Analysis (PCA) dan Cluster Analysis (CA). Selain itu, teknik analisis PCA mampu mereduksi beberapa variabelnya menjadi Principal Components (PCs), sehingga dapat diketahui apakah terdapat korelasi antar variabel [9]. Kemometrika telah banyak digunakan untuk berbagai tujuan analisis data kimia, sehingga diharapkan penulisan review ini akan bermanfaat sebagai sumber informasi mengenai potensi antioksidan minyak atsiri kunyit dan aplikasi kemometrika dalam mengidentifikasi senyawa mudah menguap dalam minyak atsiri kunyit yang berkorelasi terhadap aktivitas antioksidan. Hal ini, akan bermanfaat untuk proses determinasi senyawa fitokimia dalam herba medika yang hingga saat ini terus dikembangkan untuk tujuan peningkatan efektivitas terapi penyakit tertentu.

\section{ALAT DAN METODE}

\subsection{Alat}

Alat yang digunkaan dalam penulisan narrative overview adalah search engine artikel ilmiah dalam beberapa database seperti ACS Publications, Scopus, Science Direct, Pubmed, dan Google Scholar. 


\subsection{Metode}

Penulisan narrative review dilakukan dengan metode penelususran literatur melalui beberapa database elektronik. Pencarian literatur dalam database menggunakan kata kunci "Essential oil" AND "Curcuma longa" AND Antioxidant atau Chemometric AND "Curcuma longa" AND "Essential oil". Adapun bagan penelusuran review dapat dilihat pada Gambar 1.

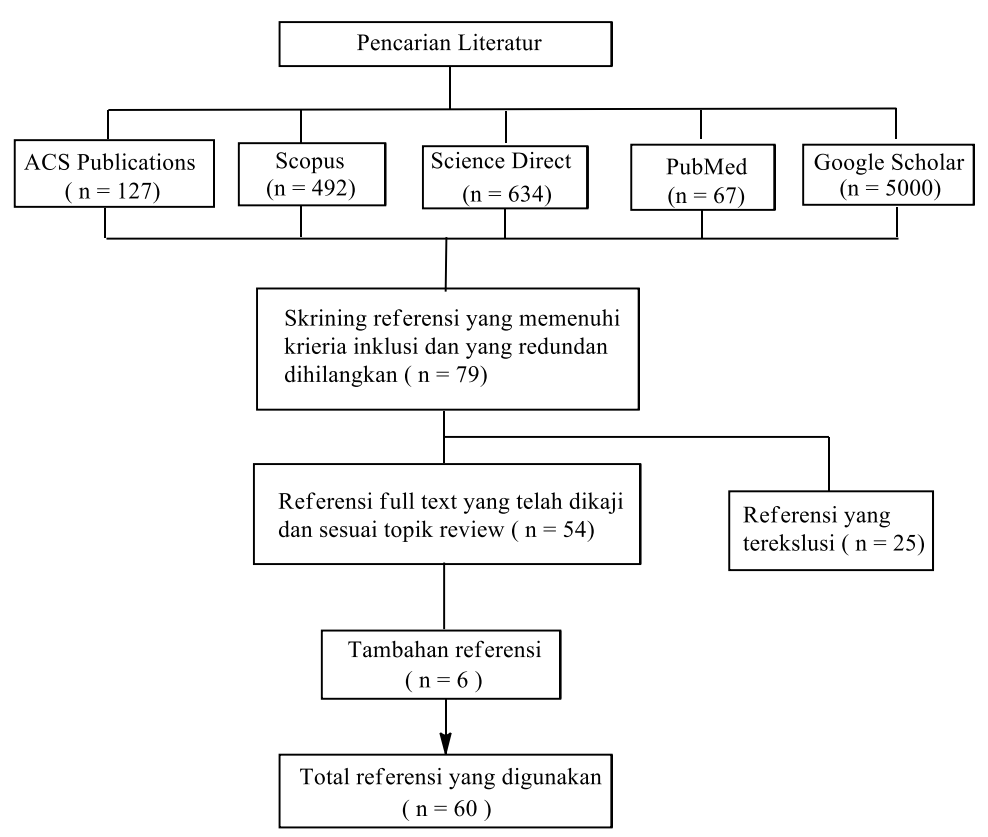

Gambar 1. Bagan penelusuran review

\section{PEMBAHASAN}

\subsection{Profil senyawa minyak atsiri kunyit}

Minyak atsiri mengandung senyawa multi-komponen dan mudah menguap. Metode yang umum digunakan dalam identifikasi senyawa kimia yang terkadung dalam minyak atsiri adalah kromatografi gas. Untuk keperluan determinasi senyawa fitokimia dan standarisasi obat herbal yang dapat meliputi komponen senyawa non-polar, minyak atsiri, asam lemak, lipid, dan alkaloid umumnya diidentifikasi menggunakan instrumen yang memiliki efektifitas dan sensitivitas yang tinggi yaitu GC-MS [12]. Proses metabolite profiling membutuhkan metode yang cepat, reliabel, sensitif, dan mampu mengidentifikasi sejumlah besar senyawa/metabolit. Teknologi spektrometri masa akan meningkat sensitivitasnya jika dikombinasikan dengan pemisahan kromatografi [14]. Selain itu, keuntungan dari teknologi ini adalah adanya protokol yang stabil untuk pengaturan dan pemeliharaan mesin, serta evaluasi dan interpretasi kromatogram [15].

Menurut penulusuran yang telah dilakukan dari beberapa database, studi terkait profiling minyak atsiri kunyit telah banyak dilakukan di China dan India utamanya serta beberapa negara lainnya seperti Amerika Serikat, Bangladesh, Brazil, Iran, Iraq, Korea, Nigeria, Pakistan, Perancis, Serbia, Spanyol, dan Taiwan. Profiling minyak atsiri kunyit yang berasal dari berbagai tempat menggunakan GC-MS, diperoleh profil kromatogram yang beragam [16-17]. Hal ini mengindikasikan bahwa senyawa kimia yang terkandung dalam minyak atsiri kunyit bervariasi, diperlihatkan dari nilai persentase dan jumlah senyawa teridentifikasi. Jika mengacu pada penelitian sebelumnya, berdasarkan analisis koefisien sensitifitas relatif besarnya persentase minyak atisiri 
yang diperoleh dari rimpang kunyit dipengaruhi oleh pemberian fosfor dan kalium, sedangkan faktor lingkungan lainnya seperti suhu, $\mathrm{pH}$, kelembapan, ketinggian, pemberian karbon organik dan nitrogen tidak signifikan mempengaruhi nilai persentase minyak atsiri kunyit [18].

Senyawa utama yang terkandung dalam minyak atsiri kunyit menurut banyaknya laporan penelitian sebelumnya, memperlihatkan data yang hampir sama diantara seluruh penelitian yang telah dilakukan di berbagai negara. Golongan senyawa yang memiliki persentase terbesar adalah seskuiterpen teroksigenasi meliputi ar-turmerone, $\alpha$-turmerone, $\beta$-turmerone. Dari keseluruhan hasil review literatur, sebagian besar hasil penelitiannya menyebutkan salah satu atau lebih dari ketiga senyawa golongan seskuiterpen teroksigenasi merupakan senyawa utama yang memiliki persentase dominan dalam minyak atsiri kunyit (dapat dilihat dalam Tabel 1).

Selain golongan seskuiterpen teroksigenasi terdapat senyawa lain yang juga disebutkan memiliki persentase dominan dalam minyak atsiri kunyit yaitu golongan monoterpen seperti $\alpha$ phellandrene dan 1,8-cineole, sedangkan senyawa lainnya merupakan minoritas [3, 19-21]. Ada beberapa senyawa lain yang memiliki persentase dominan kedua setelah golongan senyawa seskuiterpen teroksigenasi adalah $\alpha$-zingiberene (4.78\%) [22], caryophyllene (9.8\%) [23], terpinolene (15.8\%) (24), zingiberene (6.353\%) dan curcumene (5.987\%) [2], serta beberapa senyawa lainnya yang dapat dilihat pada Tabel 3. Namun ada beberapa penelitian yang melaporkan hasil yang berbeda seperti yang telah dilakukan oleh Hassan dkk. (2003) tidak menemukan golongan senyawa seskuiterpen teroksigenasi, melainkan yang dominan adalah senyawa $\beta$-sesquiphellandrene.

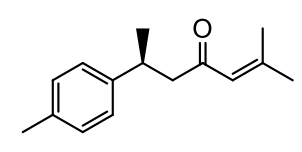

ar-turmerone

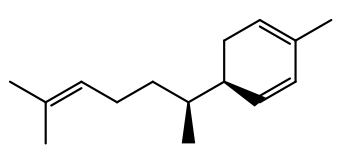

zingiberene

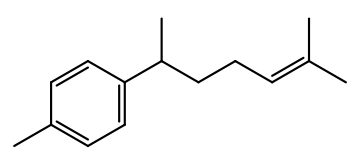

curcumene

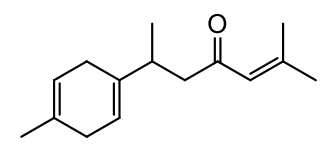

$\alpha$-turmerone

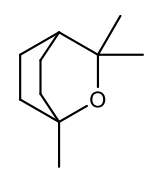

1,8-cineole

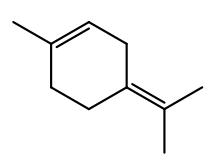

terpinolene<smiles>C=C1C=CC(C(C)CC(=O)C=C(C)C)CC1</smiles>

$\beta$-turmerone

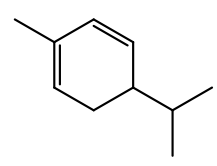

$\alpha$-phellandrene

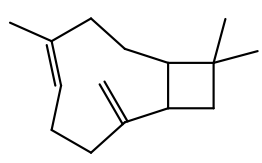

caryophyllene

Gambar 2. Struktur kimia komponen utama minyak atsiri kunyit

\subsection{Aktivitas antioksidan minyak atsiri kunyit}

Beberapa metode untuk mengevaluasi aktivitas antioksidan telah banyak dikembangkan diantaranya adalah 1) radical scavenging methods (metode penangkapan radikal) meliputi radikal 2,2'diphenyl-1-picrylhydrazyl (DPPH), 2,2'-azinobis-(3-ethylbenzothiazoline-6-sulfonic acid (ABTS*+), hidrogen, natrium oksida, dan peroksinitrit, 2) reducing power (kekuatan mereduksi) meliputi ferric reducing antioxidant power (FARP), ferotiosianat, metode fosfomolibdenum, dan cupric reducing antioxidant capacity, 3) metal chelating power, 4) inhibisi lipid peroksida menggunakan $\beta$-carotene bleaching linoleic-ferric-thiocyanate, dan metode TBA (thiobarbituric acid) (25-26). Metode penangkapan 
radikal merupakan metode yang paling umum digunakan untuk mengevaluasi aktivitas antioksidan [26]. Parameter yang digunakan untuk mengevaluasi aktivitas antioksidan pada metode penangkapan radikal adalah IC $_{50}$ yang merupakan konsentrasi sampel yang dibutuhkan untuk menangkap 50\% radikal [6]. Semakin kecil nilai IC50 dari suatu sampel uji, menunjukkan kapasitas antioksidan yang semakin poten.

Penetralan senyawa radikal umumnya melalui 2 mekanisme yaitu transfer atom hidrogen atau transfer elektron untuk mengubah senyawa radikal menjadi spesies senyawa yang stabil [25]. Mekanisme tersebut dikenal dengan hydrogen atom transfer (HAT) dimana atom $\mathrm{H}$ ditransfer ke target radikal, sehingga dapat terjadi rekombinasi radikal dan diperoleh produk yang stabil.

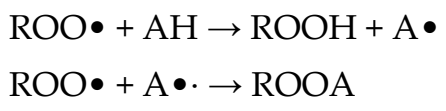

Mekanisme kedua yaitu single slectron transfer (SET) dimana satu atau lebih elektron ditransfer untuk menstabilkan senyawa radikal.

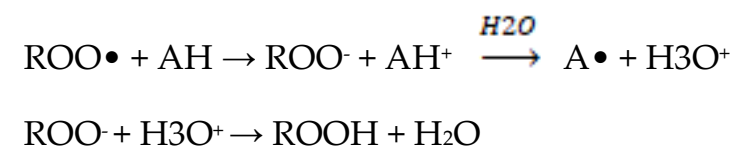

Berdasarkan hal tersebut, pembahasan review ini akan berfokus pada aktivitas antioksidan minyak atsiri rimpang kunyit yang dievaluasi menggunakan metode penangkapan radikal DPPH dan ABTS. Metode penangkapan radikal DPPH memiliki mekanisme reaksi single electron transfer dan metode penangkapan radikal ABTS diklasifikasikan dalam mekanisme hydrogen atom transfer [2]. Metode ABTS dievaluasi berdasarkan kemampuan penangkapan radikal kation ABTS•+ yang ada dalam larutan. Penangkapan radikal ABTS•+ merupakan metode yang bagus untuk mengevaluasi kapasiatas antioksidan beberapa senyawa lipofilik atau hidrofilik, karena metode ini mengevaluasi kemampuan penangkapan lipid atau radikal hidrogen peroksil dalam cairan [36].

Menurut penelitian yang telah dilakukan oleh Zhang dkk. (2017) disebutkan bahwa 19 dari 20 sampel minyak atsiri kunyit yang diperoleh dari berbagai tempat yang berbeda di China memiliki nilai $\mathrm{IC}_{50}$ yang lebih kecil dibandingkan trolox sebagai kontrol positif. Uji aktivitas antioksidan menggunakan metode penangkapan radikal DPPH diperoleh nilai $\mathrm{IC}_{50}$ trolox sebesar 10,72 $\mu \mathrm{g} / \mathrm{mL}$, sedangkan minyak atsiri yang paling poten diantara 20 sampel dari berbagai tempat tersebut memiliki IC50 4,37 $\mu \mathrm{g} / \mathrm{mL}$. Menurut penelitian yang telah dilakukan oleh Zhang dkk. (2017) disebutkan bahwa 19 dari 20 sampel minyak atsiri kunyit yang diperoleh dari berbagai tempat yang berbeda di China memiliki nilai IC 50 yang lebih kecil dibandingkan trolox sebagai kontrol positif. 
Tabel 1. Komponen senyawa kimia dalam minyak atsiri rimpang kunyit

\begin{tabular}{|c|c|c|c|}
\hline Asal & Sampel (Metode) & Komponen kimia utama & Referensi \\
\hline Faisalabad, Pakistan & Fresh rizhome (HD) & $\begin{array}{c}\text { Ar-turmerone }(25,3 \%) \text {; } \alpha \text {-turmerone }(18,3 \%) \text {; curlone }(12,5 \%) \text {; caryophyllene }(2,26 \%) \text {; } \\
1,8 \text {-cineole }(1,62 \%)\end{array}$ & $(21)$ \\
\hline Kerala, India & $\begin{array}{l}\text { Dried rizhome } \\
\quad(\mathrm{SD})\end{array}$ & $\begin{array}{c}\text { Ar-turmerone (61,78\%); curlone (12,48\%); ar-curcumene (6,11\%); phenol (3,45\%); zingiberene }(2,97 \%) ; \beta \text { - } \\
\text { sesquiphellandrene (2,81\%); 1-ethyl-4-isobutylbenzene }(2,62 \%) \text {; } \alpha \text {-bisabolene }(1,48 \%) \text {; benzene }(1,47 \%) ; \\
\text { benzaldehyde (1,44\%); 4-methyl-carbanilonitrile }(1,09 \%)\end{array}$ & $(27)$ \\
\hline Chittagong, Bangladesh & Fresh rizhome (HD) & $\begin{array}{c}\text { Ar-turmerone }(27,78 \%) ; \text { tumerone }(17,16 \%) \text {; curlone }(13,82 \%) ; \beta \text {-sesquiphellandrene }(5,57 \%) ; 2 \text {-carene }(4,78 \%) \text {; } \\
\text { zingiberene }(4,37 \%)\end{array}$ & $(22)$ \\
\hline Chittagong, Bangladesh & Fresh rizhome (HD) & $\begin{array}{c}\text { Carvacrol }(21,14 \%) ; \text { citral }(13,91 \%) ; \text { methyleugenol }(7,31 \%) ; \text { geraniol }(6,99 \%) ; \text { menthol }(5,11 \%) ; \text { caryophyllene } \\
\text { oxide }(4,14 \%)\end{array}$ & $(22)$ \\
\hline Vlasotince, Serbia & $\begin{array}{l}\text { Turmeric powder } \\
\qquad(\mathrm{HD})\end{array}$ & $\begin{array}{l}\alpha \text {-Turmerone (26\%); ar-turmerone (22,7\%); curlone }(16,8 \%) \text {; eugenol }(8,0 \%) ; \text { zingiberene }(2,8 \%), \beta \text { - } \\
\text { sesquiphellandrene }(2,8 \%) \text {; caryophyllene }(2,0 \%) \text {; ar-curcumene }(1,8 \%)\end{array}$ & (7) \\
\hline $\begin{array}{l}\text { Guangxi, Sichuan, } \\
\text { Chongqing, Yunnan, Cihna }\end{array}$ & $\begin{array}{l}\text { Fresh rizhome } \\
\qquad(\mathrm{HD})\end{array}$ & $\begin{array}{l}\text { Ar-turmerone (10,43-42,85\%); } \beta \text {-turmerone (5,13-39.54\%); } \alpha \text {-zingiberene }(0,50-25,05 \%) ; \text { ar-curcumene }(1,74 \text { - } \\
\qquad 15,70 \%) ; \beta \text {-sesquiphelladrene }(4,94-11,3 \%) ;\end{array}$ & $(28)$ \\
\hline Anhui market, China & $\begin{array}{l}\text { Rizhome powder } \\
\text { (HD) }\end{array}$ & $\begin{array}{c}\text { Ar-turmerone (6,63-35.17\%); curcumene }(2.39-11.17 \%) \text {; zingiberene }(4,27-20,93 \%) ; \beta \text {-sesquiphelladrenen } \\
(7,85-18,1 \%) \text {; cendrenol }(0,85-13.53 \%) ; \alpha \text {-bisabolene }(1,01-12,19 \%)\end{array}$ & (9) \\
\hline Sichuan, Taiwan & $\begin{array}{l}\text { Dried rizhome } \\
\qquad(\mathrm{SDE})\end{array}$ & Ar-turmerone (24,7\%); turmerone (29,5\%); turmerol $(25,7 \%)$ & $(29)$ \\
\hline Tehran, Iran & $\begin{array}{l}\text { Turmeric powder } \\
\qquad(H D)\end{array}$ & $\begin{array}{c}\text { Ar-turmerone }(24,61 \%) \text {; curlone }(11,73 \%) \text {; tumerone }(9,658 \%) ; \beta \text {-sesquiphellandrene }(7,589 \%) \text {; zingiberene } \\
(6,353 \%) \text {; curcumene }(5,987 \%)\end{array}$ & $(2)$ \\
\hline Pulau Reunion, Perancis & Fresh rizhome (SD) & $\begin{array}{l}\alpha \text {-Turmerone }(21,4 \%) ; \text { zingiberene }(11,8 \%) \text {; terpinolene }(15,8 \%) ; \beta \text {-sesquiphellandrene }(8,8 \%) ; \text { ar- } \alpha \text {-turmerone } \\
\qquad(7,7 \%) ; \beta \text {-turmerone }(7,1 \%), \beta \text {-caryophyllene }(5,7 \%), \text { ar-curcumene }(4,5 \%), 1,8 \text {-cineole }(2,0 \%)\end{array}$ & $(24)$ \\
\hline
\end{tabular}




\begin{tabular}{|c|c|c|c|}
\hline \multicolumn{4}{|l|}{ Lanjutan Tabel 1... } \\
\hline Lucknow, India & $\begin{array}{l}\text { Fresh rizhome } \\
\qquad(H D)\end{array}$ & $\begin{array}{c}\alpha \text {-Turmerone }(23,35 \%) ; \beta \text {-turmerone }(19,74 \%) \text {; myrcene }(10,51 \%) ; 1,8 \text {-cineole }(5,93 \%) \text {; ar-curcumene }(4,24 \%) ; \\
\text { ar-turmeron }(3,87 \%) ; \text {-cymene }(3,24 \%) ; \gamma \text {-terpinene }(2,32 \%) ; \\
\text { 231imachala- } 4 \text {-ol }(1,41 \%)\end{array}$ & $(30)$ \\
\hline Goias State, Brazil & $\begin{array}{l}\text { Fresh Rizhome } \\
\qquad(S D)\end{array}$ & $\begin{array}{c}\alpha \text {-Turmerone }(42,6 \%) ; \beta \text {-turmerone }(16,0 \%) ; \text { ar-turmerone }(12,9 \%) ; \alpha \text {-phellandrene }(6,5 \%) ; 1,8 \text {-cineole }(3,2 \%) ; \\
\alpha \text {-zingiberene }(1,9 \%) ; \beta \text {-sesquiphelladren }(1,4 \%)\end{array}$ & (3) \\
\hline Umuarama, PR, Brazil & $\begin{array}{l}\text { Fresh rizhome } \\
\text { (HD) }\end{array}$ & $\begin{array}{c}\text { Ar-turmerone }(50,70 \% \text { - 61,70\%); } \beta \text {-turmerone }(19,50 \% \text { - 22,01\%); } 1.8 \text {-cineole }(1,07 \%-3,14 \%) ; \alpha \text { - } \\
\text { zingiberene }(2,77 \% \text { - 4,41\%); } \beta \text {-sesquiphellandrene }(0,30 \%-3,10 \%)\end{array}$ & (20) \\
\hline Gorakhpur, India & $\begin{array}{l}\text { Fresh rizhome } \\
\qquad(\mathrm{HD})\end{array}$ & $\begin{array}{l}\text { Ar-turmerone }(24,4 \%) ; \alpha \text {-tumerone (20,5\%); } \beta \text {-turmerone }(11,1 \%) ; \beta \text {-sesquiphellandrene }(2,9 \%) \\
\text { terpinolenen }(2,7 \%) ; \alpha \text {-zingiberene }(2,5 \%) ; 6 \mathrm{R}, 7 \mathrm{R} \text {-Bisabolone }(1,7 \%)\end{array}$ & $(1)$ \\
\hline Zongkhai, China & $\begin{array}{l}\text { Fresh rizhome } \\
\text { (SD) }\end{array}$ & $\begin{array}{c}\text { Ar-turmerone }(11,81 \%) \text {; zingiberene }(8,62 \%) ; \beta \text {-sesquuiphelladren }(6,66 \%) \text {; curionen }(4,08 \%) ; \\
\text { ar-curcumene }(2,61 \%) ;\end{array}$ & (6) \\
\hline Aromaland Company, China & Turmeric oil & $\begin{array}{c}\text { Ar-curcumene }(16,4 \%) \text {; zingiberene }(16,5 \%) ; \beta \text {-sesquiphelladerene }(14,4 \%) ; \text { ar-turmerone }(16,8 \%) ; \\
\text { turmerone }(16,5 \%)\end{array}$ & $(31)$ \\
\hline $\begin{array}{c}\text { Peshawar, Khyber } \\
\text { Pakhtunkhwa, Pakistan }\end{array}$ & $\begin{array}{l}\text { Dried Rizhome } \\
\quad(\mathrm{SD})\end{array}$ & $\begin{array}{c}\beta \text {-sesquiphellandrene }(38,69 \%) ; \alpha \text {-curcumene }(18,44 \%) ; \text { p-mentha-1,4(8)-diene }(16,29 \%) ; 7 \text {-hexamethyl } \\
(6,11 \%) ; \alpha \text {-caryophyllen }(4,72 \%)\end{array}$ & $(32)$ \\
\hline Lucknow, India & $\begin{array}{l}\text { Dried rizhome } \\
\qquad(\mathrm{SD})\end{array}$ & $\begin{array}{c}\text { 1,8-Cineole }(11,2 \%) ; \alpha \text {-turmerone }(11,1 \%) ; \text { caryophyllene }(9,8 \%) ; \text { ar-turmerone }(7,3 \%), \alpha \text {-phellendrene } \\
(8,0 \%) ; \text { sesquiphellendrene }(7,1 \%) ; \text { zingibrene }(5,6 \%) ; \beta \text {-turmerone }(5,0 \%) ; \text { ar-curcumene }(4,4 \%) ; \mathrm{p} \text { - } \\
\text { cymene }(4,3 \%) ; \beta \text {-bisabolene }(2,8 \%)\end{array}$ & (23) \\
\hline Cameroon, Gerona, Spain & Fresh rizhome (SD) & $\alpha$-Turmerone $(43,1 \%) ;$ ar-turmerone $(17,6 \%) ; \beta$-turmerone $(17,5 \%) ; \alpha$-phellandrene $(3,9 \%)$ & (33) \\
\hline $\begin{array}{l}\text { Plaine-Magnien, Mauritius, } \\
\text { Iraq }\end{array}$ & Fresh rizhome (SD) & $\begin{array}{c}\alpha \text {-Turmerone (31,4\%); ar-turmerone (16,1\%); turmerol (14,6\%); terpinolene }(11,0 \%) ; \alpha \text {-zingiberene }(5,2 \%) ; \\
\beta \text {-sesquiphelladrene }(4,8 \%) ; \beta \text {-caryophyllene }(3,5 \%)\end{array}$ & $(5)$ \\
\hline $\begin{array}{l}\text { Delapan daerah di Odisha, } \\
\text { India }\end{array}$ & Fresh rizhome (SD) & $\begin{array}{l}\text { Ar-turmerone }(39,54-45,33 \%) \text {; curlone }(9,76-11,65 \%) ; \alpha \text {-phelladrene }(5,48 \%-7,66 \%) ; 1,8 \text {-cineole }(3,24- \\
\qquad 5,52 \%) ; 231 \text { imachalane }(1,65-5,49 \%), \alpha \text {-copen- } 11 \text {-ol }(2,32-5,38 \%)\end{array}$ & (17) \\
\hline
\end{tabular}




\begin{tabular}{|c|c|c|c|}
\hline $\begin{array}{l}\text { Sembilan daerah di Roma, } \\
\text { India }\end{array}$ & Fresh rizhome $(\mathrm{SD})$ & $\alpha$-Turmerone, curlone, ar-turmerone, $\beta$-sesquiphelladrenen, terpinolene, curcumene & $(16)$ \\
\hline Ondo, Nigeria & $\begin{array}{l}\text { Fresh rizhome } \\
\qquad(\mathrm{SD})\end{array}$ & $\begin{array}{l}\alpha \text {-Turmerone }(35,9 \%) ; \text { curlone }(12,9 \%) ; \text { ar-tumerone }(10,0 \%) ; 1,8 \text {-cineole }(10,3 \%) ; \alpha \text {-phellandrene }(15,5 \%) ; \\
\text { p-cymene }(2,1 \%) ; \text { terpinolene }(3,2 \%), \alpha \text {-zingiberene }(2,0 \%) ; \beta \text {-sesquiphellandrene }(1,8 \%)\end{array}$ & $(19)$ \\
\hline Delapan Provinsi di China & $\begin{array}{l}\text { Fresh rizhome } \\
\qquad(\mathrm{LEP})\end{array}$ & $\begin{array}{l}\beta \text {-Turmerone }(8,26 \text { - 31.43\%); } \alpha \text {-turmeron }(4,27-21,87 \%) \text {; ar-turmerone }(0,92-12,63 \%) \text {; zingiberene }(1,94 \text { - } \\
13,19 \%) ; \beta \text {-sesquiphelladrene }(1,02-5,92 \%) ; \text { beta-bisabolene }(0,79-3,43 \%) ; \quad \text { ar-curcumene }(0,85-3,48 \%)\end{array}$ & $(34)$ \\
\hline Zongkhai, China & $\begin{array}{l}\text { Fresh Rizhome } \\
\qquad(\mathrm{SD})\end{array}$ & $\begin{array}{c}\text { Ar-turmerone (36,04 \%); curlone (8,78 \%); } \beta \text {-turmerone }(7,05 \%) ; 8,9 \text {-dehydro-9-formyl- } \\
\text { cycloisolongifolene }(5,69 \%) ; \beta \text {-sesquiphellandrene }(5,39 \%) \text {; germacrone }(4,51 \%) \text {; ar-curcumene }(2,19 \%) ; \\
\alpha \text {-himachalene }(2.14 \%) ; \text { ledane }(2,13 \%)\end{array}$ & $(35)$ \\
\hline
\end{tabular}

\section{Keterangan :}

HD: hydrodistillation

LEP: liquid extraction pressurized
SD: steam distillation

SDE: steam distillation and solvent extraction 
Uji aktivitas antioksidan menggunakan metode penangkapan radikal DPPH diperoleh nilai IC 50 trolox sebesar $10,72 \mu \mathrm{g} / \mathrm{mL}$, sedangkan minyak atsiri yang paling poten diantara 20 sampel dari berbagai tempat tersebut memiliki $\mathrm{IC}_{50} 4,37 \mu \mathrm{g} / \mathrm{mL}$. Selain itu, kapasitas antioksidan minyak atsiri kunyit yang dievaluasi dengan penangkapan radikal ABTS juga menunjukkan potensi yang serupa. Hasil uji ABTS diperoleh nilai IC 50 trolox sebesar $11,42 \mu \mathrm{g} / \mathrm{mL}$ dan minyak atsiri yang paling poten memiliki nilai IC 50 $_{0}$ sebesar 4,21 $\mu \mathrm{g} / \mathrm{mL}$. Nilai IC 50 yang lebih kecil dibandingkan dengan trolox sebagai kontrol positif menunjukkan bahwa minyak atsiri kunyit memiliki aktivitas antioksidan yang sangat poten. Terbukti secara in vitro minyak atsiri kunyit mampu menentralkan radikal DPPH dan ABTS lebih banyak dibandingkan dengan trolox (kontrol positif). Pada studi sebelumnya potensi antioksidan pada minyak atsiri kunyit dikaitkan dengan kandungan utama dari minyak atisiri kunyit yang terdiri dari senyawa ar-turmerone, $\beta$-turmerone, ar-curcumene, $\beta$-sesquiphellandrene, curlone, curdione yang memiliki persentase dominan dari senyawa lainnya [37].

Dalam penelitian lain yang dilaporkan oleh Avanco dkk. (2017) diperoleh hasil bahwa nilai IC 50 dari minyak atsiri kunyit yang dievaluasi dengan metode DPPH adalah 10,03 mg/mL. Hasil ini sangat berbeda dengan nilai IC 50 minyak atsiri kunyit 4,50 mg/mL yang dilaporkan oleh Gounder dan Lingamallu (2012). Dalam artikel Avanco dkk. (2017) dijelaskan bahwa hal tersebut dikarenakan oleh perbedaan persentase dari senyawa ar-turmerone. Oleh karena itu, senyawa ar-tumerone dikaitkan dengan kemampuan menangkap radikal DPPH dalam minyak atsiri [3].

\subsection{Aplikasi Kemometrika untuk Mengelompokkan dan Melihat Korelasi antar Variabel pada Minyak Atsiri Kunyit}

Kemometrika merupakan cabang ilmu pengetahuan yang mengaplikasikan teori matematika dan statitistika untuk mengolah data kimia. Kemometrika banyak berkaitan dengan pengukuran data multivariat [13]. Data yang diperoleh dalam proses penelitian dengan banyaknya variabel dapat dianalisis dengan mudah menggunakan kemometrika. Pemetaan senyawa yang sangat beragam dan banyak kemiripan dalam suatu sampel yang dianalisis menggunakan metode konvensional, tidak dapat membuktikan adanya variasi kualitas atau aktivitas yang terkandung dalam sampel tersebut. Oleh karena itu, kemometrika yang merupakan ilmu gabungan antara statistika dan matematika dapat dijadikan sebagai solusi untuk determinasi keberagaman senyawa kimia yang ada di alam dengan berbagai macam aktivitasnya yang terus diteliti dan dikembangkan.

Minyak atsiri kunyit yang diisolasi dari rimpang kunyit dan berasal dari tempat yang berbeda memiliki profil senyawa yang beragam dengan nilai aktivitas antioksidan yang juga bervariasi [28], untuk mengilustrasikan perbedaan kandungan konstituen kimia diantara minyak atsiri kunyit dari beberapa tempat dapat menggunakan metode PCA dan CA. Penelitian dengan tujuan tersebut telah dilakukan oleh beberapa peneliti, namun belum ada desain penelitian yang mengkorelasikan profil senyawa minyak atsiri rimpang kunyit dengan nilai aktivitas antioksidannya menggunakan teknik PCA. Variasi analisis korelasi menggunakan PCA dapat dilihat pada Tabel 2. 
Tabel 2. Variabel analisis korelasi menggunakan PCA (28)

\begin{tabular}{|c|c|c|c|c|c|c|c|c|c|c|}
\hline \multirow[t]{2}{*}{ Sampel } & \multirow{2}{*}{$\begin{array}{c}\mathrm{IC}_{50} \\
(\mu \mathrm{g} / \mathrm{mL}) \\
\text { DPPH }\end{array}$} & \multirow{2}{*}{$\begin{array}{c}\text { IC }_{50} \\
(\mu \mathrm{g} / \mathrm{mL}) \\
\text { ABTS }\end{array}$} & \multicolumn{8}{|c|}{ Persentase kandungan senyawa (\%) } \\
\hline & & & 1 & 2 & 3 & 4 & 5 & 6 & 7 & 8 \\
\hline $\mathrm{C} 1$ & 5,21 & 4,21 & 25,04 & 0 & 12,9 & 4,78 & 7,49 & 1,79 & 7,59 & 0,74 \\
\hline $\mathrm{C} 2$ & 7,42 & 6,22 & 0,92 & 0 & 0 & 0 & 0,67 & 1,94 & 25,18 & 3,27 \\
\hline C3 & 8,69 & 8,52 & 27,26 & 5,13 & 15,7 & 6,57 & 11,3 & 1,91 & 7,77 & 0,5 \\
\hline $\mathrm{C} 4$ & 9,31 & 8,61 & 19,02 & 15,04 & 0 & 9,08 & 10,26 & 1,95 & 6,2 & 9,66 \\
\hline C5 & 8,43 & 8,6 & 6,57 & 21,22 & 3,07 & 6,5 & 14,88 & 1,15 & 4,22 & 25,05 \\
\hline C6 & 7,3 & 7,75 & 23,59 & 18,51 & 4,35 & 12,89 & 8,09 & 0,56 & 1,59 & 9,64 \\
\hline C7 & 9,2 & 8,64 & 9,99 & 37,53 & 1,74 & 11,13 & 8,9 & 0,49 & 0 & 14,05 \\
\hline $\mathrm{C} 8$ & 5,59 & 4,79 & 12,76 & 38,32 & 1,71 & 13,28 & 6,35 & 0,69 & 0 & 9,75 \\
\hline C9 & 7,13 & 7,93 & 16,5 & 39,54 & 1,45 & 14,61 & 4,94 & 0,72 & 0 & 5,5 \\
\hline C10 & 4,74 & 5,44 & 15,34 & 21,23 & 5,8 & 8,61 & 0 & 10,11 & 4,06 & 15,7 \\
\hline C11 & 7,41 & 6,61 & 27,11 & 12,54 & 9,09 & 12,55 & 0,14 & 8,89 & 2,78 & 6,35 \\
\hline C12 & 7,41 & 6,47 & 23,1 & 6,93 & 14,8 & 6,8 & 11,78 & 0 & 0 & 7,81 \\
\hline C13 & 7,46 & 7,57 & 19,59 & 11,23 & 15,2 & 8,17 & 0 & 14,15 & 1,93 & 10,6 \\
\hline C14 & 7,13 & 8 & 22,2 & 13,53 & 10,75 & 8,74 & 0,07 & 10,36 & 2,03 & 10,43 \\
\hline C15 & 7,08 & 6,88 & 36,88 & 10,12 & 6,01 & 12,67 & 0 & 4,05 & 0 & 1,67 \\
\hline C16 & 5,83 & 6,2 & 11,92 & 42,54 & 1,21 & 14,25 & 5,78 & 0,75 & 0 & 8,25 \\
\hline C17 & 4,64 & 5,44 & 42,85 & 0 & 0 & 11,75 & 2,1 & 2,87 & 2,12 & 0,25 \\
\hline C18 & 4,37 & 5,17 & 35,28 & 18,15 & 3,13 & 16,24 & 2,62 & 0 & 0,8 & 0 \\
\hline
\end{tabular}

Keterangan:
1: ar-turmerone
2: $\beta$-turmerone
3: ar-curcumene
4: curlone
5: $\beta$-sesquiphellandrene $\quad$ : cubenol
7: germacrone
8: $\alpha$-zingiberene

PCA telah banyak digunakan sebagai teknik analisis yang mampu mereduksi dimensi dataset original dengan menjelaskan korelasi antar nilai variabel yang begitu banyak menjadi nilai variabel yang lebih kecil dengan sebutan principal components (PCs) tanpa menghilangkan banyak informasi [9]. Setelah mengurangi dimensi variabel yang kompleks menjadi PCs, PCA score plot akan mampu menampilkan pemisahan kelas, sedangkan untuk melihat korelasi antar variabel akan dinterpretasikan dalam loading plot.

Meskipun PCA dapat menampakkan beberapa kelompok dalam analisis data multivariat, akan tetapi PCA tidak selalu sukses melakukannya. Ada metode lain yaitu CA yang memiliki tujuan eksplisit untuk mencari kelompok [38]. CA merupakan suatu metode untuk membagi sekelompok objek (sampel) ke dalam suatu kelompok (kelas), sehingga objek yang sejenis akan berada dalam kelompok yang sama [9]. Pengelompokan didasarkan pada perolehan jarak Euclidean dan dapat ditampilkan dalam suatu dendogram. Jika beberapa sampel terklasifikasi dalam 1 kluster itu berarti bahwa sampel tersebut memiliki jarak Euclidean yang dekat dan mengindikasikan bahwa sampel tersebut memiliki kemiripan [13].

Dalam penelitian yang dilakukan oleh Li dkk., (2009) dari 33 sampel simplisia rimpang kunyit yang diperoleh dari berbagai daerah di China dikelompokkan menggunakan teknik PCA dan CA berdasarkan variasi kromatogram yang diperoleh dari hasil identifikasi minyak atsiri kunyit 
menggunakan GC-MS. Menurut hasil analisis, pengelompokan menggunakan menggunakan PCA dan CA menunjukkan kemiripan [39].

Beberapa penelitian yang melakukan evaluasi aktivitas antioksidan minyak atsiri kunyit mengkorelasikan aktivitas antioksidannya dengan senyawa kimia yang memiliki persentase tertinggi dalam minyak atsiri tanpa membuktikannya dengan bantuan metode analisis tertentu. Seperti yang dilaporkan Legault dan Pichette (2007), potensi antioksidan pada minyak atsiri kunyit dikaitkan dengan kandungan utama dari minyak atisiri kunyit yang terdiri dari ar-turmerone, $\beta$ turmerone, ar-curcumene, $\beta$-sesquiphellandrene, curlone, dan curdione. Menurut penelitian yang telah dilakukan oleh Singh dkk., (2010) melaporkan hasil yang serupa bahwa minyak atsiri kunyit memiliki kapasitas antioksidan yang tinggi dan dikorelasikan dengan senyawa ar-tumerone dan $\alpha$ turmerone sebagai komponen utama yang banyak terkandung dalam minyak atsiri kunyit. Penjelasan terkait hal ini dalam beberapa literatur belum didukung dengan analisis menggunakan kemometrika.

Kemometrika dapat diaplikasikan untuk melihat korelasi antar variabel. Menurut hasil penelusuran literatur, penulis tidak menemukan desain penelitian yang sesuai dengan tujuan ini. Oleh karena itu, penulis melakukan analisis kemometrika menggunakan metode PCA untuk melihat senyawa yang berkorelasi terhadap aktivitas antioksidan dengan menggunakan variasi profil senyawa minyak atsiri kunyit dalam penelitian Zhang dkk. (2017b) [28]. Variabel yang digunakan untuk analisis PCA dalam hal ini adalah senyawa mudah menguap yang terkandung dalam minyak atsiri kunyit dan aktivitas antioksidan yang diidentifikasi menggunakan metode pengangkapan radikal DPPH dan ABTS. Senyawa yang dianalisis merupakan senyawa utama yaitu sejumlah 8 senyawa yang memiliki persentase dominan. Diantaranya adalah senyawa ar-turmerone, $\beta$-turmerone, ar-curcumene, curlone, $\beta$-sesquiphellandrene, cubenol, germacrone, dan $\alpha$-zingiberene. Data analisis korelasi variabel terdapat dalam Tabel 2. Jenis matriks yang digunakan dalam analisis PCA adalah "correlation" karena variabel yang dianalisis memiliki satuan yang berbeda. Korelasi antar variabel dapat dilihat dalam loading plot yang ditampilkan pada Gambar 3.

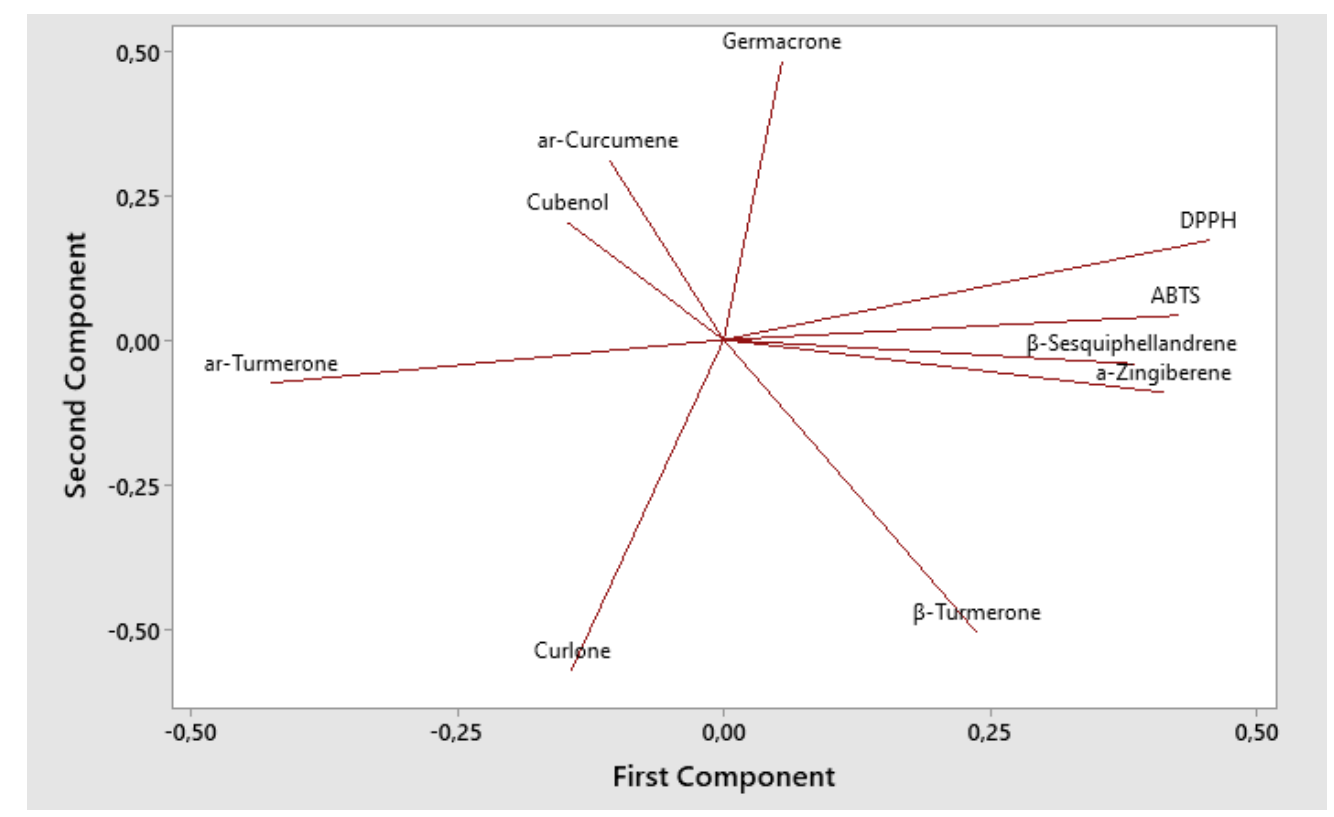

Gambar 3. Loading plot hasil analisis PCA profil senyawa dan aktivitas antioksidan minyak atsiri kunyit 
Sudut antar vektor menunjukkan korelasi antar variabel. Menurut loading plot yang diperoleh dari hasil analisis kemometrika PCA, variabel aktivitas antioksidan ( IC $_{50}$ ) hasil uji menggunakan metode penangkapan radikal DPPH dan ABTS berpencar membentuk sudut yang dekat dengan $180^{\circ}$ yang menunjukkan korelasi negatif terhadap senyawa ar-turmerone. Hal ini berarti bahwa semakin besar konsentrasi senyawa ar-turmerone dalam minyak atsiri kunyit maka semakin kecil nilai IC50 menurut hasil uji penangkapan radikal DPPH dan ABTS atau dapat dijelaskan bahwa kenaikan konsentrasi senyawa ar-turmerone berbanding lurus dengan potensi aktivitas antioksidan minyak atsiri kunyit. Hasil ini sesuai dengan penjelasan dalam penelitian Avanco dkk. (2017) yang menyatakan bahwa penangkapan radikal DPPH dikorelasikan dengan adanya senyawa ar-turmerone dalam minyak atsiri.

\section{KESIMPULAN}

Analisis data multivariat dari minyak atsiri kunyit yang meliputi profil senyawa dan aktivitas antioksidan dapat dikelompokkan menggunakan kemometrika dengan teknik analisis PCA dan CA. Identifikasi senyawa mudah menguap dalam minyak atsiri kunyit yang berkorelasi terhadap aktivitas antioksidan menurut data penelitian Zhang dkk, (2017) dianalisis menggunakan matriks "correlation" dengan teknik PCA diperoleh hasil bahwa tingginya kandungan senyawa arturmerone dalam minyak atsiri kunyit berbanding lurus dengan potensi antioksidan minyak atsiri kunyit. Menurut hasil uji aktivitas antioksidan yang telah dilakukan peneliti sebelumnya, minyak atsiri kunyit dapat digunakan sebagai antioksidan alami yang poten karena memiliki nilai IC 50 yang lebih kecil dari control positif (trolox).

Ucapan terima kasih: Penulis mengucapkan terima kasih yang sebesar-besarnya kepada seluruh peneliti yang telah melakukan penelitian yang terkait dalam review ini. Penulis juga berterima kasih kepada Universitas Gadjah Mada atas fasilitas open access e-journal dalam beberapa database yang sangat dibutuhkan dalam penelusuran literatur untuk penulisan review.

\section{Referensi}

1. Singh, G., Kapoor, I.P.S., Singh, P., Heluani, C.S. De, Lampasona, M.P. De \& Catalan, C.A.N. Comparative study of chemical composition and antioxidant activity of fresh and dry rhizomes of turmeric (Curcuma longa Linn.), Food and Chemical Toxicology, 2010, 48(4):1026-1031.

2. Nasiri, S.L., Hosseini, S.E. \& Shekarchi, M., Chemical Composition and Antioxidant Activity of Essential Oil from Turmeric (Curcuma longa) Rhizomes, International Journal of Food and Safety, 2015, 6(3):185-196.

3. Avanco, G.B., Ferreira, F.D., Mallmann, C.A., Brugnari, T., Abreu Filho, B.A. de, Mikcha, J.M.G. \& Machinski, M. Curcuma longa L. essential oil composition, antioxidant effect, and effect on Fusarium verticillioides and fumonisin production, Food Control, 2017, 73:806-813.

4. Dosoky, N.S. \& Setzer, W.N. Chemical composition and biological activities of essential oils of curcuma species, Nutrients, 2018, 10(9):10-17.

5. Jugreet, B.S., Mahomoodally, M.F., Sinan, K.I., Zengin, G. \& Abdallah, H.H. Chemical variability, pharmacological potential, multivariate and molecular docking analyses of essential oils obtained from four medicinal plants, Industrial Crops and Products, 112394, 2020.

6. Zhang, L., Yang, Z., Chen, F., Su, P., Chen, D., Pan, W., Fang, Y., Dong, C., Zheng, X. \& Du, Z., 2017a, Composition and bioactivity assessment of essential oils of Curcuma longa L. collected in China, Industrial 
Crops and Products, 2020, 109, August, 60-73.

7. Stanojević, J.S., Stanojević, L.P., Cvetković, D.J. \& Danilović, B.R. Chemical Composition, Antoxidant and Antimicrobial Activity of the Turmeric Essential Oil (Curcuma longa L.), Advanced Technology, 2015, 4(2): $19-25$.

8. Ferreira, F.D., Kemmelmeier, C., Arrotéia, C.C., Da Costa, C.L., Mallmann, C.A., Janeiro, V., Ferreira, F.M.D., Mossini, S.A.G., Silva, E.L. \& Machinski, M., Inhibitory effect of the essential oil of Curcuma longa L. and curcumin on aflatoxin production by Aspergillus flavus Link, Food Chemistry, 2013, 136(2):789-793.

9. Hu, Y., Kong, W., Yang, X., Xie, L., Wen, J. \& Yang, M., 2014, GC-MS combined with chemometric techniques for the quality control and original discrimination of Curcumae longae rhizome: Analysis of essential oils, Journal of Separation Science, 37(4):404-411.

10. Leverve, X., Oxidative stress and antioxidants, Cahiers de Nutrition et de Dietetique, 2009, 44(5):219-224.

11. Saccol, E.M.H., Londero, É.P., Bressan, C.A., Salbego, J., Gressler, L.T., Silva, L.V.F., Mourão, R.H.V., Oliveira, R.B., Llesuy, S.F., Baldisserotto, B. \& Pavanato, M.A. Oxidative and biochemical responses in Brycon amazonicus anesthetized and sedated with Myrcia sylvatica (G. Mey.) DC. and Curcuma longa L. essential oils, Veterinary Anaesthesia and Analgesia, 2017, 44(3):555-566.

12. Al-Rubaye, A.F., Hameed, I.H. \& Kadhim, M.J. A Review: Uses of Gas Chromatography-Mass Spectrometry (GC-MS) Technique for Analysis of Bioactive Natural Compounds of Some Plants, International Journal of Toxicological and Pharmacological Research, 2017, 9(01):81-85.

13. Gad, H.A., El-Ahmady, S.H., Abou-Shoer, M.I. \& Al-Azizi, M.M. Application of chemometrics in authentication of herbal medicines: A review, Phytochemical Analysis, 2013, 24(1):1-24.

14. Fiehn, O., Kopka, J., Dörmann, P., Altmann, T., Trethewey, R. \& Willmitzer, L., Metabolite profiling for plant functional genomics, Nature Biotechnology, 2000, 18(11):1157-61.

15. Lisec, J., Schauer, N., Kopka, J., Willmitzer, L. \& Fernie, A.R. Gas chromatography mass spectrometry-based metabolite profiling in plants, Nature Protocols, 2006, 1(1):387-396.

16. Sandeep, I.S., Kuanar, A., Akbar, A., Kar, B., Das, S., Mishra, A., Sial, P., Kumar, P., Nayak, S. \& Mohanty, S. Agroclimatic zone based metabolic profiling of turmeric (Curcuma Longa L.) for phytochemical yield optimization, Industrial Crops \& Products, 2016, 85:229-240.

17. Sahoo, A., Kar, B., Jena, S., Dash, B., Ray, A., Sahoo, S. \& Nayak, S. Qualitative and Quantitative Evaluation of Rhizome Essential Oil of Eight Different Cultivars of Curcuma longa L. (Turmeric), Journal of Essential Oil-Bearing Plants, 2019, 22(1): 239-247.

18. Sandeep, I.S., Das, S., Nayak, S. \& Mohanty, S. Chemometric Profile of Curcuma longa L . Towards Standardization of Factors for High Essential Oil Yield and Quality, Proceedings of the National Academy of Sciences, India Section B: Biological Sciences, 2016b, 1-6.

19. Oyemitan, I.A., Elusiyan, C.A., Onifade, A.O., Akanmu, M.A., Oyedeji, A.O. \& McDonald, A.G. Neuropharmacological profile and chemical analysis of fresh rhizome essential oil of Curcuma longa (turmeric) cultivated in Southwest Nigeria, Toxicology Reports, 2017, 4:391-398.

20. Ferrari, M.P. de S., Queiroz, M. dos S., Andrade, M.M. de, Alberton, O., Gonçalves, J.E., Gazim, Z.C. \& Magalhães, H.M. Substrate-associated mycorrhizal fungi promote changes in terpene composition, antioxidant activity, and enzymes in Curcuma longa L. acclimatized plants, Rhizosphere, 2020, 100191.

21. Naz, S., Ilyas, S., Parveen, Z. \& Javed, S. Chemical Analysis of Essential Oils from Turmeric (Curcuma longa) Rhizome Through GC-MS, Asian Journal of Chemistry, 2010a, 22(4):3153-3158

22. Chowdhury, J.U., Nandi, N.C., Bhuiyan, M.N.I. \& Mobarok, M.H., Essential Oil Constituents of The Rhizomes of Two Types of Curcuma longa of Bangladesh, Bangladesh Journal of Scientific and Industrial 
Research, 2008, 43(2):259-266.

23. Raina, V.K., Srivastava, S.K., Jain, Ł.N., Ahmad, A., Syamasundar, K. V \& Aggarwal, K.K., Essential oil composition of Curcuma longa L . cv . Roma from the plains of northern India, Flavour and Fragance Journal, 2002, 17: 99-102.

24. Taylor, P., Chane-ming, J., Vera, R., Chalchat, J., Cabassu, P. \& Chane-ming, J. Chemical Composition of Essential Oils from Rhizomes, Leaves and Flowers of Curcuma longa L. from Reunion Island, Journal Essential Oil. 2002, 14:45-48.

25. Schaich, K.M., Tian, X. \& Xie, J. Reprint of Hurdles and pitfalls in measuring antioxidant efficacy: A critical evaluation of ABTS, DPPH, and ORAC assays, Journal of Functional Foods, 2015, 18:782-796.

26. Rohman, A., Widodo, H., Lukitaningsih, E., Windarsih, A., Rafi, M. \& Nurrulhidayah, A.F. Review on in vitro antioxidant activities of curcuma species commonly used as herbal components in Indonesia, Food Research, 2020, 4(2):286-293.

27. Liju, V.B., Jeena, K. \& Kuttan, R., An evaluation of antioxidant, anti-inflammatory, and antinociceptive activities of essential oil from Curcuma longa. L, Indian Journal of Pharmacology, 2011, 43(5):526-531.

28. Zhang, L., Yang, Z., Wei, J., Su, P., Chen, D., Pan, W., Zhou, W., Zhang, K., Zheng, X., Lin, L., Tang, J. \& Du, Z., Contrastive analysis of chemical composition of essential oil from twelve Curcuma species distributed in China, Industrial Crops and Products, 2017b, 108:17-25.

29. Tsai, S.-Y., Huang, S.-J., Chyau, C.-C., Tsai, C.-H., Weng, C.-C. \& Mau, J.-L. Composition and antioxidant properties of essential oils from Curcuma rhizome, Asian J.Arts Sci., 2011, 2(1):57-66.

30. Bansal, R.P., Bahl, J.R., Garg, S.N., Naqvi, A.A., Kumar, S. \& Plants, A. Differential Chemical Compositions of the Essential Oils of the Shoot Organs, Rhizomes and Rhizoids in the Turmeric Curcuma longa Grown in Indo-Gangetic Plains, Pharmaceutical Biology, 2002, 40(5):384-389.

31. Yu, Y., Chen, F., Wang, X., Adelberg, J., Barron, F.H., Chen, Y. \& Chung, H.Y. Evaluation of Antioxidant Activity of Curcumin-Free Turmeric (Curcuma longa L.) Oil and Identification of Its Antioxidant Constituents, American Chemical Society, 2008, 14:152-164.

32. Hassan, W., Gul, S., Rehman, S., Kanwal, F., Siddique, M., Fazal, H., Shah, Z., Rahman, A.U. \& Bt, J. Gas chromatography coupled with mass spectrometric characterization of Curcuma longa : Protection against pathogenic microbes and lipid peroxidation in rat's tissue homogenate, 2003, 29(2):615-621.

33. Sado, K.S.L., Belletti, N., Tchoumbougnang, F., Essia-Ngang, J.J., Montanari, C., Tabanelli, G., Lanciotti, R. \& Gardini, F., Effect of mild heat treatments on the antimicrobial activity of essential oils of Curcuma longa, Xylopia aethiopica, Zanthoxylum xanthoxyloides and Zanthoxylum leprieurii against Salmonella enteritidis, Journal of Essential Oil Research, 2015, 27(1):52-60.

34. Qin, N.Y., Yang, F.Q., Wang, Y.T. \& Li, S.P. Quantitative determination of eight components in rhizome (Jianghuang) and tuberous root (Yujin) of Curcuma longa using pressurized liquid extraction and gas chromatography - mass spectrometry, Journal of Pharmaceutical and Biomedical Analysis, 2007, 43:486-492.

35. Zheng, Y., Pan, C., Zhang, Z., Luo, W., Liang, X., Shi, Y., Liang, L., Zheng, X., Zhang, L. \& Du, Z. Antiaging effect of Curcuma longa L. essential oil on ultraviolet-irradiated skin, Microchemical Journal, 2020, 104608.

36. Gounder, D.K. \& Lingamallu, J. Comparison of chemical composition and antioxidant potential of volatile oil from fresh, dried and cured turmeric (Curcuma longa) rhizomes, Industrial Crops and Products, 2012, 38(1):124-131.

37. Legault, J. \& Pichette, A. Potentiating effect of $\beta$-caryophyllene on anticancer activity of $\alpha$-humulene, isocaryophyllene and paclitaxel, Journal of Pharmacy and Pharmacology, 2007, 59(12):1643-1647.

38. Miller, J.C. \& Miller, J.N. Statistic and Chemometrics for Analytical Chemistry, Fifth Edition, Ashford Colour 
Press, Hants, 2005.

39. Li, S.-Y. \& Li, S.-P. Antioxidant activities of essential oil of Curcuma longa and Curcuma wenyujin, International Journal of Essential Oil Therapeutics, 2009, 3:31-34.

(C) 2020 by the authors. Submitted for possible open access publication under the terms

(c) and conditions of the Creative Commons Attribution (CC BY) license (http://creativecommons.org/licenses/by/4.0/). 